\title{
Forestry as an object of legal regulation
}

\author{
Oksana Grechenkova ${ }^{1, *}$ \\ ${ }^{1}$ Institute of Service and Entrepreneurship (branch) of DSTU in Shakhty, str., 147, 346500 Shevchenko, \\ Russia
}

\begin{abstract}
The article is devoted to the study and analysis of the use of forests, including for agriculture. The use of forests is the central institution of forest law, the concept of "use of forests" is one of the main concepts in the Forest Code of the Russian Federation. The legislator refused to use the terms" forest management law"," forest management", which were used in the Forest Code of the Russian Federation in 1997. The meaning of the concept of" forest use "and its relationship with the concept of" forest management", which is traditionally used in the science of forest law, is defined. From a scientific point of view, the term "forest use" coincides in its meaning with the term "forest management".
\end{abstract}

\section{Introduction}

The concept of forest management can be formulated as follows: "The right to use forests should be understood as the possibility provided by law for their economic exploitation and the extraction of useful properties and income from them."

Thus, the right of forest use can be defined as the subjective right to extract the useful properties of the forest as a natural object. The essence of forest management is to use the useful natural properties of forests, and not to use the land surface occupied by forests. Since forests perform extremely important ecological functions (climate-regulating, waterprotecting, sanitary-hygienic, protective, health-improving, recreational and other useful properties), forest management has an ecological essence.

Legal law Institute forest management opredelyaetsya as a set of legal norms that establish the conditions and procedure for multi-use, preservation and restoration of forest environment, the rights and obligations of forest users based on the interests of society to get wood and non-wood forest products, the use of other useful properties forests and protection forests and other objects of nature. We'll look at it in more detail in the next chapter.

Types of forest management in themselves represent different directions of using the benefits of the forest as a natural object and natural resource. In the implementation of forest management, the land surface plays a secondary role.

Not all types of forest use under the Forest Legislation are types of forest use. It is quite clear that, for example, the development of mineral deposits has nothing to do with the use of the useful natural properties of forests as a natural object and resource. On the contrary, the development of mineral resources often involves the destruction of forests.

\footnotetext{
* Corresponding author: grechenkovak@mail.ru
} 
The types of forest management should include those activities that are directly related to the extraction of the useful properties of forest resources.

There is a large proportion of subjectivism, which creates prerequisites for the pursuit of personal (public servants) and private (economic entities) benefits in addition to or instead of national-state and public benefits, which are aimed at extracting the activities of, in this case, forestry [1].

Under the interests of peace and security of mankind, the interests of ensuring the physical existence of an indefinite circle of people (humanity as a whole or demographic groups) from any threats, the source of which is the human factor [2].

Rapid identification of innovative opportunities and their implementation by enterprises through the qualitative use of human and intellectual capital can lead the enterprise to an innovative development model [3].

This makes it expedient to conduct intersectoral economic and legal research that initiates the further formation of the legal sphere of innovative activity with anti-criminogenic potential [4].

Special attention should be paid to agriculture and fishing.

Their role as a neutralizer of overall risk is entirely due to the negative covariance of their returns with those of other industries in other regions. At the same time, these industries themselves show the lowest levels of yield volatility, which also affects the risk assessment $[5]$.

\section{Methods and subject of the study.}

The method of forest law is characterized by a combination of imperative and dispositive principles in the regulation of forest relations. None of these methods prevail in the regulation of forest relations. For example, in environmental law, the mandatory method prevails with the generally accepted approach (without taking into account the natural resource norms governing the use and protection of individual natural objects). In civil law, the dispositive method prevails. In forest law, they are combined approximately in the proportion of 50: 50 . This combination is a feature of forest law.

The procedure for the use of forests is based largely on a contractual basis, that is, potential forest users have the right to choose whether or not to enter into a lease agreement for a forest land plot. In this case, the dispositivity of the order of forest use is clearly visible. But at the same time, legal entities that have signed a lease agreement for a forest plot are required to comply with the procedure for using forests, as well as fulfill a number of obligations. Thus, on the one hand, the rules governing the use of forests are dispositive, on the other hand, mandatory regulation is also applied.

The state's interest in regulating forest relations and the importance of forest relations for society is obvious. Russia's forests are the largest ecosystem. The state of the entire natural environment depends on its condition. It is impossible to observe the environmental rights of citizens to a favorable environment without proper legal regulation of forest relations.

Moreover, forest law establishes a specific legal regime for the legal regulation of forests and forest areas.

\section{Identification of problems and ways to solve them.}

On forested land, the right of forest use is usually inextricably linked to the right of land use: you cannot use the forest without using the land that serves as a spatial operational basis and a means of production. When the exercise of the right of forest use is impossible without the 
use of the lands of the state forest fund (when logging, secondary forest uses, except for public ones), the right of land use is of an official nature."

In the implementation of forest management, the right of land use does not have an independent character, since it is subordinate to the right of forest use.

So, the types of forest use, based on the analysis of Article 25 and other articles of the LC of the Russian Federation, include the following types of forest use:

1) wood harvesting;

2) preparation of oleoresin;

3) harvesting and harvesting of non-wood forest resources;

4) harvesting of forest food resources and collection of medicinal plants;

5) implementation of activities in the field of hunting;

6) implementation of research activities, educational activities;

7) implementation of recreational activities;

8) establishment of forest plantations and their exploitation.

Table 1. Types and forms of forest use

\begin{tabular}{|l|l|}
\hline types of forest use & forms of forest use \\
\hline wood harvesting & basic \\
\hline preparation of oleoresin & basic \\
\hline $\begin{array}{l}\text { harvesting and harvesting of non-wood forest } \\
\text { resources }\end{array}$ & basic \\
\hline $\begin{array}{l}\text { harvesting of forest food resources and } \\
\text { collecting medicinal plants }\end{array}$ & basic \\
\hline $\begin{array}{l}\text { implementation of activities in the field of } \\
\text { hunting }\end{array}$ & basic \\
\hline $\begin{array}{l}\text { implementation of research and educational } \\
\text { activities }\end{array}$ & additional \\
\hline implementation of recreational activities & additional \\
\hline $\begin{array}{l}\text { establishment and operation of forest plantations } \\
\text { (agricultural activities) }\end{array}$ & additional \\
\hline
\end{tabular}

The management of hunting and hunting, at first glance, refers only to the use of the animal world. However, the use of forests for hunting and forest management can be found in many ways in common. Both of these types of nature management are carried out in the forest, which is an ecosystem that includes the animal world. A broad understanding of the forest includes the animal world. The state of the animal world depends on the state of the forests that are the nutrient base for it. Hunting management is associated with forest development activities. So, on the forest areas provided for hunting management, it is allowed to erect temporary buildings and implement the improvement of these forest areas. According to the forest legislation, when developing forests on the basis of an integrated approach, the organization of the use of forests, as well as the creation and operation of forest infrastructure facilities, is carried out. Thus, it can be seen that the actual management of hunting falls under the activities of forest development.

It is determined that in modern Russia (2019) the consumers pay a lot of attention to the indicators of innovations during determination of quality of goods and services. Consumers' opinion is taken into account in modern Russia. Quality of the considered goods and services in 2019 grew, as compared to 2015, due to improvement of their innovative characteristics. Based on this, it is recommended-in the mid-term-to continue the set course of state and corporate management of quality of goods and services in Russia and to pay more attention to improvement of their innovative characteristics [6-8]. 
To address the question, does the use of forests for hunting to the forest, you can refer to the Forest code of the Russian Federation of 1997, it Seems no accident that the Forest code of the Russian Federation 1997 attributed to the types of forest use forest areas for the needs of hunting.

It can be concluded that the use of forests for hunting is complex and also applies to forest management. The forest is an ecosystem, is the habitat of objects of the animal world. Therefore, wildlife and forests, as well as activities for their use, are closely interrelated. For the conservation and development of wildlife, certain restrictions on the implementation of forest management, especially on hunting grounds, are necessary.

The right of forest use should be distinguished from the right of land use. Researchers define land-use rights differently. The right of forest use from the right of land use can be distinguished as follows. If land use right has as its object the earth, which have a specific legal regime, subject to the rights of the forest is the forest itself.

Some scientists believed that the land on which forests grow cannot be an object of independent land use rights. We can agree with this at the present time, taking into account the current LC of the Russian Federation.

Thus, during the construction, reconstruction, and operation of both forest infrastructure objects and objects that are not related to the creation of forest infrastructure, the use of the forest as a direct object does not occur on the lands of the forest fund. In these cases, the object of forest use is land that is covered or not covered by forest. Despite the fact that these types of land use are carried out in the forest, the forest in these cases is not an object of use.

A number of types of forest use in the Russian Federation are actually types of land use: for example, agriculture, construction, reconstruction, operation of linear objects, cultivation of forest fruit, berry, ornamental, medicinal plants, cultivation of planting material of forest plants (seedlings, seedlings), etc. Therefore, it is difficult to recognize them as types of forest management. Forest management is, first of all, the use of the useful properties of the forest as a natural object. In the above-mentioned types of activities, deforestation occurs due to the implementation of construction activities.

Many organizations and automated data processing systems are engaged in the analysis of logistics (ALS) of high-tech equipment. Therefore, the initial data and the results of the analysis should be presented in a standardized form. This requires an integrated information model that describes all relevant data elements, their attributes, and their relationships. In ALS, the tools that control the operation of high-tech equipment are an important component of the information system [9].

It seems that the complete destruction of forests (as a natural object) without reforestation measures is difficult to recognize its use, even with a stretch. This is contrary to all the principles of forest management, enshrined in Article 1 of the LC of the Russian Federation. The above types of forest use are types of land use, since in these cases the properties of the land plot are used to be the spatial basis for the placement of buildings, structures, structures. Land use is of a different nature from forest management, and they should not be confused, much less substituted for one concept by another. The Forest Code of the Russian Federation regulates land relations, if they are not regulated by land legislation (item 2 of Article 3 of the RF Land Code).

Taking into account the considered understanding of land use, the types of land use carried out on the lands of the forest fund should include those types of forest use that primarily use the useful properties of the land, and not the natural qualities of the forests, namely:

1) agriculture;

2) cultivation of forest fruit, berry, ornamental plants, medicinal plants;

3) cultivation of planting material of forest plants (seedlings, seedlings);

4) the use of forests for the performance of works on the geological study of the subsurface, for the development of mineral deposits; 
5) construction and operation of reservoirs and other artificial water bodies, as well as hydraulic structures and specialized ports;

6) construction, reconstruction, operation of linear objects);

7) processing of wood and other forest resources;

8) carrying out religious activities;

9) other types carried out in accordance with the intended purpose of the land on which these forests are located.

These types of forest use are the types of land use on the lands of the forest fund, since they contain signs of land use activities. They are by their nature types of land use carried out on forest plots located on the lands of the forest fund.

An agro-town will support to national economy, making goods and thus using technology of the Russian production and introducing a ready-made product to the market with worthy quality cultivating attachment and trust to its own product in potential consumers. The main advantage of an agro-town is solution of the problem of sale of agricultural products on reasonable prices which at the moment cannot be fixed due to the lack of relevant institutes (integrity of buyers, transparency of the market). The fair price in this case is defined at the agro-exchange house which is created along with an agro-town. [10].

Forestry managers bear financial and legal responsibility, which consists in applying financial sanctions to offenders, which are measures of financial and legal coercion [11].

As a result, it is necessary to use an economic and legal approach when developing contract terms for the delivery of goods, taking into account the norms of international law, the national legislation of the supplier country and in accordance with the calculations of the contract price and payment terms [12].

\section{The results of the study.}

The classification was based on the criterion of the forest to act as an ecosystem with the predominant role of tree and shrub vegetation. The same types of forest use, in which they are partially destroyed without reforestation, should not be attributed to forest management.

The concept of "forest use" is different from the concept of "forest management". Therefore, when describing a person who uses forest and land resources in a forest, it is logical to use the term "forest user". However, this term is discordant and unusual in use, it is not well-established in science. For this reason, for brevity and euphony in the work, forest users will be called not only those who carry out forest management, but also land use in the forest.

The essence of using forests is as follows. The use of forests should be rational. This means that they need to be protected. Rational use of natural resources means preserving the quality of the natural environment and natural resources, on the one hand, and achieving a national model of production and consumption in which the development of natural resources ensures economic growth and sustainable development of society. In other words, the rational use of forests means their protection.

The norms of the legislation on the rational use and protection of forests require the protection of the object of use during its operation. The nature of the legal protection of forests is determined by the nature and features of the forest management process. Forest management law and legal protection of forests are elements of a unified system of legal norms regulating the process of forest management and ensuring the preservation of forests. The rational use and protection of forests, their dialectical connection should be ensured by an adequate reflection in the legislation of the laws of the development and existence of forests as an element of the biogeocenosis, which is expressed in the relationship of the rights and obligations of the subjects of forest use. 
The close relationship between the use and protection of forests and the right to use forests is also determined by the fact that it is inherent in the nature of the use of natural resources. It is as a result of the exercise of the right of forest use that there is a need to protect natural objects (protection from misuse), i.e. to ensure, first of all, compliance with the rules of rational use of them. The forest legislation clearly shows the continuity of the legal protection of forests and their rational use, since this is the most important forestry law, according to which logging and reforestation should be synonymous. In other words, the method, time and territory of logging (or other types of forest use) should be organized in such a way as not to interfere with natural reforestation, which is the basis for the use of forests in the future. The use of forests should take into account the concept of sustainable development. Sustainable development is defined as development that meets the needs of the present, but does not threaten the ability of future generations to meet their own interests. In other words, sustainable development is an environmentally sound economic and social development.

It is necessary to organize the use of forests in such a way that it is sustainable. It is no accident that the organization of rational use of forests is called a strategically important task in the Concept of Forestry Development. The essence of sustainable forest use is to limit the maximum amount of forest resources withdrawn from the forest, due to the rate of their natural recovery.

An important feature of forest management, enshrined in the forest legislation of the Russian Federation, is that it is carried out taking into account the needs of the population. Thus, the right of citizens to freely and free of charge stay in the forests (in all, and not only in the forests on the lands of the forest fund) and to collect berries, mushrooms, nuts and other fruits is enshrined.

The Rostov region is entirely located in the steppe zone, which determines the nature of the vegetation covering it. In the past, before the beginning of active human intervention in nature, it was dominated by an age-old virgin steppe, from which there were insignificant islands on the slopes of gullies, on the edges of forests, as well as in the form of small plots belonging to horse farms and forestry enterprises - mainly in the eastern regions.

The remaining areas that are convenient for processing are either plowed or, to varying degrees, knocked out by cattle. Donskoi Krai is one of the most-poor regions of the country (forest land area is $2.4 \%$, while the percentage of the southern Federal district at $6.2 \%$, Russian Federation - 46,5\%), less only in the Astrakhan region (1.8\%) and the Republic of Kalmykia $(0,2 \%)$. The lion's share of these areas $(70 \%)$ is occupied not by natural, but by artificial forests.

Forests are located on land: - forest resources, their area is 360.6 thousand hectares or $96.3 \%$ of the total forest area of the region; - settlements, where urban forests are located with an area of 14.0 thousand hectares or $3.7 \%$ of all forests. The largest areas of forests are concentrated in the central and northern zones of the region.

All the forests of the region are classified as protective forests, their main purpose is to perform water protection, protective, sanitary-hygienic, and health-improving functions. Of the total area of forests in the Rostov region, natural forests account for no more than $30 \%$. They are divided into bayrachny (growing in gullies; floodplain (growing in floodplains of rivers); arenny (growing on sandy massifs). The Rostov region is rightfully considered the birthplace of steppe afforestation in Russia.

The area of valuable forests for 2020 in the Rostov region decreased by 7.3 percent, including state protective forest strips-by 4.4 percent, anti-erosion forests - by 69.7 percent, forests of scientific or historical significance - by 84.0 percent, spawning forest strips-by 31.8 percent. At the same time, the area of forests located in desert, semi-desert, forest-steppe, forest-tundra zones, steppes, and mountains has increased by more than 12 times. Participants in civil turnover have the right to enter into obligations that are not directly provided for by 
law, but most fully meet their individual needs, including to conclude contracts that are not directly provided for by civil law [13].

\section{Conclusion}

Thus, it can be concluded that all types of forest use by their nature should be divided into types of forest use and types of land use.

Currently, the contribution of the forest sector to the Russian economy is significantly lower than the estimated potential and similar indicators of other countries that are similar to Russia in terms of wood reserves and harvesting. This situation has resulted from the orientation of domestic producers mainly to low-margin segments - roundwood, lumber and plywood, as well as underutilization of export potential.

It is determined that in modern Russia (2019) the consumers pay a lot of attention to the indicators of innovations during determination of quality of goods and services. Consumers' opinion is taken into account in modern Russia. Quality of the considered goods and services in 2019 grew, as compared to 2015, due to improvement of their innovative characteristics. Based on this, it is recommended-in the mid-term-to continue the set course of state and corporate management of quality of goods and services in Russia and to pay more attention to improvement of their innovative characteristics [14].

Over the past decade, Rostov region of the Southern Federal District in Russia has experienced a major reduction in agricultural production due to climate variability and imperfect institutional mechanisms. Rural communities and agricultural producers, especially in small and medium scale businesses, have been affected by climate change and human-induced disasters in the form of drought, floods, and unusual hot and cold weather [15].

The objectives of the Strategy for the Development of the forest complex of the Russian Federation until 2030 are: to achieve sustainable forest management, innovative and effective development of the use, protection, protection and reproduction of forests, ensuring the rapid growth of the forest sector of the economy, social and environmental security of the country, unconditional fulfillment of Russia's international obligations in terms of forests; improving the long-term competitiveness of the forest industry and increasing the contribution of the forest complex to the socio-economic development of Russia.

The achievement of these goals is hindered by the following problems:

- low wood consumption per unit area of operational forests;

- insufficient efficiency of reforestation, protection and protection of forests;

- low relevance of information about forest resources;

- excessive administrative barriers;

- low degree of use of forest raw materials, which worsens the economy of the industry;

- limited scale of the domestic market, insufficient to create new production facilities in isolation from export markets;

- low investment attractiveness of the industry due to country factors;

- low level of technical, scientific and personnel support;

- imperfection of the regulatory and technical framework in the field of forestry and related industries.

The target vision of the forest complex implies the formation of an economically stable, globally competitive group of industries that meets Russia's domestic demand for forest products, is integrated into the global market and the international division of labor, and operates on the basis of sustainable forest management and the preservation of the biosphere role of forest 


\section{References}

1. O. Grechenkova, Journal of advanced research in law and economics 8(3), 821-828 (2017) doi: 10.14505/jarle.v8.3(25).15

2. O. Grechenkova, Y. Kuzmenko, The future of the global financial system: downfall or harmony series 57, 612-621 (2019) doi: 10.1007/978-3-030-00102-5

3. E. Cherkesova, E. Grevtseva, N. Demidova, A. Suhova, Journal of advanced research in law and economics 6(3), 543-550 (2015) doi: 10.14505/jarle.v6.3(13).09

4. J. Gornostaeva, I. Kushnaryova, N. Tregulova, Journal of entrepreneurship in emerging economies 10(3) (2018) doi: 10.1108/JEEE-12-2017-01

5. M. Malkina, T. Economicus, 16(3), 118-131 (2018) doi: 10.23683/2073-6606-2018-163-118-130

6. E. Popkova, A. Giyazov, In the book: Growth Poles of the Global Economy: Emergence, Changes and Future Perspectives, series "Lecture Notes in Networks and Systems" Plekhanov Russian University of Economics. (Luxembourg, 2020)

7. E. Popkova, B. Sergi, Journal of Intellectual Capital 21(4), 565-581 (2020) doi: 10.1108/JIC-09-2019-0224

8. E. Popkova, International Journal for Quality Research 14(2), 329-346 (2020) doi: 10.24874/IJQR14.02-01

9. V. Kuznetsova, D. Kondusov, A. Serdyuk, A. Sergeev, Russian engineering research 10, 892-896 (2017) doi: 10.3103/S1068798X17100136

10. V. Prokhorova, E. Zakharova, A. Gladilin, A. Molchan, International Review of Management and Marketing 6(S6), 191-196 (2016)

11. L. Barashyan, International Review of Management and Marketing 6(S6), 235-240 (2016)

12. T. Skvortsova, G. Pratsko, J. Isakova, V. Sevumyan, Internation journal of economics and business administration 8, 395-403 (2020) DOI: 10.35808/IJEBA/433

13. N. Antonova, E. Lunyova, Journal of advanced research in law and economics 8(3), 708713 (2017) doi: 10.14505/jarle.v8.3(25).02

14. E. Popkova, I. Morozova, The international entrepreneurship and management journal, 15(2), 589-597 (2019) DOI: 10.1007/s11365-018-0522

15. S. Shokri, A. Arkhipov, O. Belokrylova, Y. Filonenko, The world of Russia 26(2), 82102 (2017) 